\title{
Networks of entrepreneurs driving the Triple Helix: two cases of the Dutch energy system
}

\author{
Claudia Werker ${ }^{1}$, Jolien Ubacht ${ }^{1 *}$ and Andreas Ligtvoet ${ }^{2}$
}

\author{
* Correspondence: \\ j.ubacht@tudelft.nl \\ ${ }^{1}$ Faculty of Technology, Policy \& \\ Management, Delft University of \\ Technology, Delft, The Netherlands \\ Full list of author information is \\ available at the end of the article
}

\begin{abstract}
Entrepreneurs are often envisioned as small private start-up firms operating against all odds. Here, we investigate how in the context of the Triple Helix various entrepreneurs form communities and drive institutional and technological change. To theoretically shape a socialized view of entrepreneurship, we use the Triple Helix approach. Our empirical basis is a highly regulated sector driven by various agents, i. e. the Dutch energy system. As it depends very much on natural gas and relies less on renewables compared to similar countries, we analyse two cases where entrepreneurs drove the uptake of renewable energy sources.

In our paper, we investigate how entrepreneurs from the private, public and academic sectors drive the evolution of the Triple Helix. From our results, two general features of entrepreneurship in the Triple Helix emerge. First of all, private stand-alone enterprises do not mirror entrepreneurs at large. Second, networks of various entrepreneurs are much more common and much more complex than usually anticipated. More specifically, we find that there are rather divergent developments in Dutch energy systems. Whereas in the case of Aardwarmte Den Haag, a number of key players collaborated in order to realize one specific technology, in the LochemEnergie case, we see a project-to-project approach supported by subsidies. In both cases, a variety of entrepreneurs from the private, public and academic sectors with different roles, goals, incentives, resources, knowledge and policy levers drive the development of their energy system. It depends on the actual situation on who has the incentives and resources to be in charge and act and to include others when it seems necessary.

Entrepreneurs in such a set-up require particular skills including the ability to engage with their (knowledge) network, identify gaps, attract new participants and motivate the new and existing participants. Entrepreneurs managing these networks handle a whole range of semi-unpredictable actors and environmental factors that also influence each other; therefore, they can be defined as truly complex sociotechnological systems. As the development of local energy initiatives unfold along the way, entrepreneurs have to be flexible and open to organizational change. While large organizations such as municipalities or large multinational companies are usually less flexible, they might create space for smaller entrepreneurial activities by supporting individuals, start-ups or academics in finding novel solutions. At the same time, a major role for public entrepreneurs lies in stimulating and subsidizing entrepreneurs and their networks.

(Continued on next page)
\end{abstract}


(Continued from previous page)

The analytical framework provided here can be used to study the principles of the Triple Helix concept in a dynamic environment in which technological innovation requires the expertise and capabilities of multiple types of actors. Its function is not only to identify roles and types of entrepreneurs and their incentives, but to also assess which resources (knowledge, skills, subsidies) they can contribute to the initiative.

Keywords: Entrepreneurs, Complexity, Technological systems, Energy system, The Netherlands, Triple Helix

\section{摘 要}

创业者往往被看作不顾一切地经营小型私营初创企业的人们。在这里，我们探讨 在三螺旋背景下,各种创业者如何形成共同体,如何推动体制和技术变革。为了在 理论上形成社会化的创业观，我们采用三螺旋途径。我们的经验基础是一个由各 种代理机构驱动的高度调节部门-—荷兰能源系统。由于它非常依赖天然 气，而且对可再生能源的依赖程度要低于其它相似国家，我们分析了创业者驱动可 再生能源利用的两种情况。

在本文中，我们探讨来自私营、公共和学术界的创业者如何推动三股螺旋的进化 发展。从我们的结果来看,在三螺旋中出现了创业的两个一般特征。首先,私营的 独立企业没有反映创业者的规模。第二,各种创业者网络比通常预期的要普遍得 多,也要复杂得多。更具体地说, 我们发现荷兰能源系统有相当不同的发展。而在 Aardwarmte Den Haag 的案例中一些关键参与者为实现一个具体的技术而合作； 而在LochemEnergie的案例中，我们看到一个获得政府补贴的项目。在这两种情况 下，来自私营、公共和学术界的各种创业者,有着不同的角色、目标、激励、资 源、知识和政策杜杆的,共同推动其能源系统的发展。谁有动机和资源来负责和 采取行动,并在必要时包括其他人,取决于实际情况。

在这样的体制下，创业者需要具备特定的技能，包括介入(知识)网络、识别差 距、吸引新参与者、激励新的和现有的参与者。管理这些网络的创业者处理一 系列相互影响的半不可预测的行为主体和环境因素,这些可以被定义为真正复杂 的社会技术系统。由于本地能源动议的发展,创业者们必须灵活多变,随时迎接组 织变革。大型机构如市政当局或大型跨国公司等通常不那么灵活，它们可能通过 支持寻找新的解决方案个人、初创企业或学者,为小型企业活动创造空间。同 时，公共创业者的主要作用在于刺激和赞助创业者及其网络。

这里提供的分析框架可用于研究动态环境中三螺旋概念的原理,其中技术创新需 要多类型主体的专门知识和能力。它的职能不仅是确定创业者的角色、类型及 其动机，而且也为了评估他们能为这项动议贡献哪些资源(知识、技能、赞助)。 关键词: 创业者,复杂性,技术系统,能源系统,荷兰,三螺旋

\section{Résumé}

Les entrepreneurs sont souvent considérés comme de petites start-up privées fonctionnant contre vents et marées. Nous étudions comment, dans le contexte de la Triple Hélice divers entrepreneurs forment des communautés et conduisent des changements institutionnels et technologiques. En vue de formaliser théoriquement une vision socialisée de l'entrepreneuriat, nous utilisons l'approche de la Triple Hélice. Notre base empirique est. un secteur hautement réglementé, piloté par divers agents, à savoir le système énergétique néerlandais. Comme il dépend beaucoup du gaz naturel et moins des énergies renouvelables par comparaison avec des pays similaires, nous analysons (Continued on next page) 
(Continued from previous page)

deux cas où les entrepreneurs ont conduit l'adoption de sources d'énergie renouvelable.

Dans notre article, nous étudions comment les entrepreneurs du secteur privé, du secteur public et du monde universitaire influencent l'évolution de la Triple Hélice. De nos résultats, émergent deux aspects généraux de l'entreprenariat dans le cadre de la Triple Hélice. Tout d'abord, les entreprises autonomes privées ne reflètent pas les entrepreneurs en général. Deuxièmement, les réseaux de différents entrepreneurs sont beaucoup plus fréquents et beaucoup plus complexes qu'on ne le pense. Plus précisément, il existe des développements plutôt divergents dans les systèmes énergétiques néerlandais. Alors que dans le cas d'Aardwarmte Den Haag, un certain nombre d'acteurs clés ont collaboré pour réaliser une technologie spécifique, dans celui de LochemEnergie, une approche de projet à projet soutenue par des subventions est. notée. Dans les deux cas, divers entrepreneurs des secteurs privé et public ainsi que du monde universitaire ayant des rôles, des objectifs, des incitations, des ressources, des connaissances et des leviers de politique différents, stimulent le développement de leur système énergétique. Cela dépend de qui, en situation, est. en possession des mécanismes d'incitation et des ressources pour prendre en charge, agir et inclure d'autres entrepreneurs quand cela s'avère nécessaire.

Dans une telle configuration, des compétences particulières sont nécessaires aux entrepreneurs, dont la capacité à s'engager avec leur réseau (de connaissances), d'identifier les lacunes, d'attirer de nouveaux participants et de motiver des participants nouveaux et les anciens. Les entrepreneurs gérant ces réseaux ont à faire avec toute une gamme d'acteurs et de facteurs environnementaux semi-imprévisibles qui s'influencent aussi mutuellement, et peuvent donc se définir comme des systèmes socio-technologiques vraiment complexes. Au fur et à mesure que le développement des initiatives locales en matière d'énergie se déroule les entrepreneurs doivent en chemin être flexibles et ouverts aux changements organisationnels. Bien que de grandes organisations telles que les municipalités ou les grandes entreprises multinationales soient généralement moins souples, elles pourraient créer de l'espace pour des activités entrepreneuriales plus limitées en aidant les individus, les start-ups ou les universitaires à trouver des solutions innovantes. Un rôle majeur des entrepreneurs publics consiste à stimuler et à subventionner les entrepreneurs et leurs réseaux.

Le cadre analytique décrit dans cette analyse peut être utilisé pour étudier les principes du concept de la Triple Hélice dans un environnement dynamique dans lequel l'innovation technologique nécessite l'expertise et les capacités d'acteurs de différents types. Sa fonction est. non seulement d'identifier les rôles et les types d'entrepreneurs et leurs incitations, mais également d'évaluer quelles ressources (connaissances, compétences, subventions) peuvent contribuer à l'initiative.

\section{Mots clés}

Entrepreneurs, Complexité, Systèmes technologiques, Système énergétique, Pays-Bas, Triple Hélice

\section{Resumo}

Os empresários são muitas vezes idealizados como novas pequenas empresas privadas que operam contra todas as adversidades. Aqui, nós investigamos como, no contexto da Hélice Tríplice, vários empreendedores formam comunidades e impulsionam mudanças institucionais e tecnológicas. Para teoricamente moldar uma visão socializada do empreendedorismo, usamos a abordagem da Hélice Tríplice. Nossa base empírica é um setor altamente regulado, impulsionado por vários agentes, ou seja, o sistema de energia holandês. Por depender muito do gás natural e pouco de energias renováveis em comparação com países similares, analisamos dois casos em que os empresários (Continued on next page) 
(Continued from previous page)

conduziram a absorção de fontes de energia renováveis.

Em nosso artigo, investigamos como empresários do setor privado, público e acadêmico conduzem a evolução da Hélice Tríplice. Dos nossos resultados, surgem duas características gerais do empreendedorismo na Hélice Tríplice. Em primeiro lugar, as empresas isoladas privadas em geral não retraram os empreendedores. Em segundo lugar, as redes de vários empresários são normalmente muito mais comuns e muito mais complexas do que o esperado. Mais especificamente, nós encontramos que há desenvolvimentos bastante divergentes nos sistemas de energia holandeses. Considerando que, no caso da Aardwarmte Den Haag, vários atores importantes colaboraram para obter uma tecnologia específica, no caso LochemEnergie, vemos uma abordagem de projeto apoiado por subsídios. Em ambos os casos, uma variedade de empresários do setor privado, o setor público e da academia com diferentes papéis, metas, incentivos, recursos, conhecimento e alavancas políticas impulsionam o desenvolvimento de seu sistema energético. Depende da situação específica quem tem os incentivos e os recursos para assumir o comando e agir e para incluir os outros quando isso for necessário.

Os empreendedores em tal configuração precisam de habilidades específicas, incluindo a capacidade de se envolver com sua rede (de conhecimento), identificar lacunas, atrair novos participantes e motivar os participantes novos e os já existentes. Os empresários que gerenciam essas redes lidam com uma série de atores semi-imprevisíveis e fatores ambientais que também influenciam uns aos outros, portanto, podem ser definidos como sistemas sócio-tecnológicos verdadeiramente complexos. À medida que o desenvolvimento das iniciativas energéticas locais se desdobram ao longo do tempo, os empresários devem ser flexíveis e abertos a mudanças organizacionais. Enquanto as grandes organizações, como municípios ou grandes empresas multinacionais, geralmente são menos flexíveis, eles podem criar espaço para atividades empresariais menores, apoiando indivíduos, start-ups ou acadêmicos na busca de novas soluções. Ao mesmo tempo, um papel importante para os empresários públicos consiste em estimular e subsidiar empresários e suas redes.

O quadro analítico fornecido aqui pode ser usado para estudar os princípios do conceito da Hélice Tríplice em um ambiente dinâmico em que a inovação tecnológica requer a experiência e as capacidades de vários tipos de atores. Sua função não é apenas identificar papéis e tipos de empresários e seus incentivos, mas também avaliar quais recursos (conhecimento, habilidades, subsídios) podem contribuir para a iniciativa.

\section{Palavras-chave}

Empreendedores, Complexidade, Sistemas Tecnológicos, Sistema de Energia, Holanda, Hélice Tríplice

\section{Аннотация}

Предприниматели достаточно часто ассоциируются с маленькими частными старт-ап фирмами, противостоящими всем возможным трудностям. Однако, в настоящей статье, в контексте Тройной спирали мы исследовали различные формы предпринимательства, генерирующие институциональные и технологические изменения. Для того, чтобы теоретически обосновать социальный подход к предпринимательству, мы использовали трехспиральную модель. Наша эмпирическая база представляет собой жестко регламентируемую отрасль - Энергетический сектор Нидерландов. Поскольку он в значительной степени зависит от природного газа и связан с возобновляемыми ресурсами по (Continued on next page) 
(Continued from previous page)

аналогии с другими странами, мы изучили два примера, в которых предприниматели

стимулировали потребление возобновляемых энергетических ресурсов.

В нашей работе мы исследовали то, как предприниматели, вышедшие их частного,

публичного и академического секторов, стимулируют развитие Тройной спирали. По

нашим данным, идентифицированы две основные особенности предпринимательства

в Тройной спирали. Первая из них заключается в том, что частные самостоятельные

предприятия не являются олицетворением предпринимательства в целом. Во-вторых, сети различных предпринимателей встречаются намного чаще и отличаются большей сложностью, чем принято думать. В частности, мы обнаружили, что существуют разнонаправленные исследования в Энергетической системе Нидерландов. В то время как, в рамках проекта Aardwarmte Den Haag несколько ключевых игроков объединились для того, чтобы реализовать одну уникальную технологию, в случае LochemEnergie мы видим несколько самостоятельных проектов, поддерживаемых вместе субсидиями. В обоих случаях, множество предпринимателей из частного, публичного и академического секторов, имеющие различные роли, цели, стимулы, ресурсы, знания и стратегии, обеспечивают развитие энергетической системы страны. В каждой конкретной ситуации могут возникнуть различные мотивы и ресурсы, которые могут оказывать влияние на тех, кому это необходимо.

Предприниматели в подобных ситуациях должны обладать определенными навыками, в том числе способностью взаимодействовать с источниками информации, идентифицировать риски, привлекать новых участников, мотивировать новых или действующих членов сети. Предприниматели, управляющие такими сетями, берут на себя широкий круг обязанностей по управлению частично непрогнозируемыми акторами и факторами окружающей среды, что оказывается влияние на каждого участника, поэтому они могут быть охарактеризованы как истинная сложная социо-технологическая системы. По мере развития локальных энергетических инициатив, предприниматели вынуждены быть гибкими и открытыми к организационным изменениям. В то время как крупные компании (например, муниципалитеты) или крупные транснациональные компании обычно менее гибки, они могут сформировать пространство для развития более мелких предпринимательских инициатив путем поддержки отдельно взятых лиц, старт-апов или ученых в их попытках найти свежие решения. В то же время, главенствующая роль публичного предпринимателя опирается на стимулирование и субсидирование предпринимателей и их сетей.

Аналитическая модель, представленная здесь, может быть использована для изучения принципов Тройной спирали в динамическом окружении, в котором технологические инновации требуют экспертизы и ресурсов нескольких типов участников. Результатом ее является не только идентификация ролей и типов предпринимателей и их мотивов, но и предоставление доступа к ресурсам (знания, умения, субсидии), которые важны в конкретном проекте.

\section{Ключевые слова}

Предприниматели, Сложность, Технологические системы, Энергетические системы, Нидерланды, Тройная спираль

\section{Resumen}

La imagen común de un empresario es la de un líder solitario, a la cabeza de un pequeño emprendimiento, avanzando contra viento y marea. Aquí investigamos cómo los empresarios van más allá de esa imagen pues forman comunidades de (Continued on next page) 
(Continued from previous page)

emprendimiento y son también agentes de transformación institucional y

tecnológica. Usamos la Tripe Hélice como un marco conceptual. Nuestro asidero

empírico es el sector energético holandés. Este sector depende principalmente del

gas natural pero esta coyuntura nos permitió estudiar dos casos en que los

empresarios impulsaron la adopción de fuentes de energía renovables.

Nuestros resultados revelan dos características generales del emprendimiento en la

Triple Hélice. En primer lugar, las empresas privadas independientes no reflejan a los empresarios en general. Segundo, las redes de varios empresarios son mucho más comunes y mucho más complejas de lo que se suele anticipar. Más específicamente, encontramos que el sistema de energía holandés va desarrollando por caminos divergentes. Mientras que en el caso de Aardwarmte Den Haag, varios actores clave colaboraron para realizar una tecnología específica, en el caso de LochemEnergie vemos un enfoque de proyecto a proyecto respaldado por subsidios. En ambos casos, una variedad de empresarios impulsa el desarrollo del sector; sin embargo, el accidente de quien cuenta con recursos determina la centralidad de uno u otro empresario en la red resultante.

Los empresarios en tal configuración requieren habilidades especializadas, incluidas la capacidad de interactuar con su red (de conocimiento), identificar vacíos, atraer nuevos participantes y motivar a los participantes nuevos y existentes. Los empresarios que manejan estas redes navegan sistemas socio-tecnológicos verdaderamente complejos. A medida que el desarrollo de las iniciativas energéticas locales se desarrolla, los empresarios deben ser flexibles y abiertos a cambios organizacionales. Si bien las grandes organizaciones, como los municipios o las grandes empresas multinacionales, suelen ser menos flexibles, estas podrían crear espacios para actividades de emprendimiento mediante el apoyo a individuos, nuevas empresas, y académicos en la búsqueda de soluciones novedosas. Al mismo tiempo, un rol clave para los empresarios públicos es el de estimular y subsidiar a los empresarios privados y sus redes.

De manera más general, nuestro marco analítico puede servir para examinar los principios de la Triple Hélice en un entorno dinámico en el que la innovación tecnológica requiere de experiencia y capacidades de múltiples tipos de actores. Este marco no solo permite identificar los roles y tipos de empresarios y sus incentivos, sino también evaluar qué recursos (conocimiento, habilidades, subsidios) pueden aportar a la innovación.

Palabras clave

Empresarios, complejidad, sistemas tecnológicos, sistemas de energía, Holanda, Triple Hélice.

\section{Multilingual abstract}

Please see Additional file 1 for translation of the abstract into Arabic.

\section{Introduction}

Envisioning entrepreneurship usually goes hand in hand with picturing the stand-alone entrepreneur, i.e. a small private start-up firm operating against all odds. The popular legend of the stand-alone entrepreneur points to numerous famous examples, such as William Hewlett and David Packard, Walt Disney or Steve Jobs (Audia \& Rider, 2005). Yet, stand-alone entrepreneurs are rather exceptional. The legend about them "... offers misleading insights to would-be entrepreneurs, because it suggests an undersocialized view of the entrepreneurial process." (Audia \& Rider, 2005, p. 21). In fact, entrepreneurs 
come in all kinds of forms and normally need the support of at least a couple of crucial network partners (Gurrieri, 2013). Particularly when technological innovations are systemic, i.e. affect the characteristics of the supporting systems, entrepreneurs rely on their network partners.

The legend of the stand-alone entrepreneur has been guiding theories that have had substantial influence, i.e. the traditional linear model of innovation as well as networked entrepreneurship. In the traditional linear model of innovation, basic research provides the foundations for technology which in turn lays the groundwork for innovation (Godin, 2006). This model suggests a clear-cut division of labour, i.e. universities working on basic research, public or private research organizations on technology and stand-alone entrepreneurs primarily on innovation. Networked entrepreneurship also sees stand-alone entrepreneurs centre-stage when it comes to innovation by depicting them as the heart of successful high-technology regions, such as the famous example of Silicon Valley (Gibson \& Stiles, 2000). The idea is that private entrepreneurs in successful high-tech regions emerge from or substantially benefit from nearby university research. However, evidence shows that the effects of university research are usually rather modest (Woodward, Figueiredo, \& Guimarães, 2006).

In the following, we want to do justice to the various forms of entrepreneurs, to their relationships and to the communities they build in order to drive institutional and technological change. In particular, we aim at better understanding diversity and knowledge flows between entrepreneurs in the energy system and beyond. In building our more socialized view of entrepreneurship, we use the Triple Helix model as suggested by Etzkowitz and Leydesdorff (2000). They show, on a rather aggregated level, how the private, public and academic sectors interact and collaborate to solving specific problems. In our study, we disaggregate to the level of the individual entrepreneur to show how the roles of entrepreneurs from the different sectors change in time. How communities of entrepreneurs emerge and evolve, driven by various kinds of entrepreneurs, has been particularly addressed in the context of civic communities (Henton, Melville, \& Walesh, 1997).

In our paper, we look into how entrepreneurs from the private, public and academic sectors drive the evolution of the Triple Helix. From our results, we can derive a better understanding of how different stakeholders manage, support and stimulate entrepreneurs in the Triple Helix. Our empirical data stems from the Dutch energy system. Like many Northwest European countries, such as the UK, Belgium, Denmark, France and Germany, the Netherlands have been transforming their energy system by focusing on domestic electricity and heat solutions (Ligtvoet \& van Barneveld, 2016). What sets the Netherlands apart is that they depend very much on natural gas and have not been able to meet the energy targets set for renewable energy (European Commission, 2017). Thus, whereas the Dutch government still emphasizes a moderated approach in its recent energy agenda (Ministry of Economic Affairs, 2016), stakeholders of the Dutch energy system have felt the urgency for an energy transition (Sociaal Economische Raad, 2013). As a consequence, the transformation of the Dutch energy system has not been driven top-down based on a clear blueprint but bottom-up by many networks of entrepreneurs participating in recent and ongoing technological and political changes (Elzenga \& Schwenke, 2014).

Our paper is organized as follows: Our theoretical concept (see the "Entrepreneurs and their relationships in the Triple Helix" section) goes beyond the current notions of 
stand-alone entrepreneurs or networked entrepreneurship in two ways: First, we include various forms of entrepreneurship containing academic, public and private entrepreneurs (see the "Entrepreneurs in the private, public and academic sectors" section). Second, we show how the evolution of entrepreneurs' networks drive and shape their activities and how network partners' roles change in time to solve emerging problems (see the "Entrepreneurs' relationships beyond their own sector" section). In the "Recent institutional and technological change of the Dutch energy system" section, we set the scene for our empirical analysis by sketching the institutional and technological changes of the Dutch energy system in recent decades. Following that, we introduce two specific cases of the Dutch energy system highlighting the fact that entrepreneurship goes far beyond the stand-alone entrepreneur and thrives on relationships with partners from other sectors (see the "Networks of entrepreneurs in the Dutch energy system: two cases" section). Eventually, in the "Tentative framework of entrepreneurship in the Triple Helix" section, we derive a tentative theoretical concept of entrepreneurs in the Triple Helix, showing its applicability beyond the Dutch energy system. We round the paper with a short summary of our results, recommendations for management and policy aimed at the various kinds of entrepreneurs and their supporting network, and future research topics (see the "Conclusions" section).

\section{Entrepreneurs and their relationships in the Triple Helix}

Generally speaking, entrepreneurial activities emerge from groups of specialized individuals creating and capturing value, e.g. in the form of publicly available knowledge, novel goods and services (Landström, Harirchi, \& Åström, 2012). In complex technological systems, entrepreneurship relates to collaborative activities pursuing a shared vision of how to develop and deploy science and technology (Bailetti, 2012). As analysing entrepreneurship in the context of the supporting network requires more than the standard analysis of entrepreneurship, we employ and further develop the concept of entrepreneurship by embedding the Triple Helix approach. In particular, we discuss two crucial elements: one, the various forms of entrepreneurship that exist (see the "Entrepreneurs in the private, public and academic sectors" section), and the relationships between entrepreneurs, particularly the roles the different entrepreneurs take in dynamic networks as captured by the concept of the Triple Helix (see the "Entrepreneurs' relationships beyond their own sector" section).

\section{Entrepreneurs in the private, public and academic sectors}

Entrepreneurship plays a role in all walks of life including the public and the academic sector as well as civic society, thereby going far beyond stand-alone activities of startups and small- and medium-sized companies (SMEs) in the private sector (Gibson \& Stiles, 2000). Innovation, technological change and dynamics do not only stem from entrepreneurial activities by start-ups and SMEs but also from intrapreneurial activities within large and multinational corporations, from public organizations, from political entities, from social activities by non-governmental organizations (NGOs) and from civic networks as well as from academics.

Distinguishing entrepreneurs regarding their goals unfolds a whole spectrum with private entrepreneurs pursuing private goals at the one end of the spectrum and public 
entrepreneurship pursuing public goals at the other end of the spectrum. Private entrepreneurs explore and exploit business opportunities in order to provide novel products or services as well as more efficient production processes (Bailetti, 2012) (Landström, Harirchi, \& Åström, 2012). They come in very different forms such as start-ups, spin-offs, SMEs and large and multinational corporations. In its pure form, private entrepreneurship is driven by private goals such as making profit, exploiting one's ideas and talents or employing oneself (Klein, Mahoney, McGahan, \& Pitelis, 2010) (Landström, Harirchi, \& Åström, 2012). At the other end of the spectrum, public entrepreneurs, i.e. governmental bodies, usually focus on public goals, including ethical considerations about emerging new technological solutions (European Commission, 2013) (Klein, Mahoney, McGahan, \& Pitelis, 2010). Particularly, governmental entrepreneurs need to constantly revise the political mindset in relation to emerging technological and market opportunities, because they play a crucial role in setting the institutional framework and standards for newly emerging networks, e.g. by new laws or regulations (Edquist, 2011). Hereby, they are in a good position to accommodate social values and to make responsible innovation possible.

In between private and public entrepreneurship, there are entrepreneurs pursuing both public and private goals, i.e. academics, social entrepreneurs or civic communities. When societal goals and public values become an integral part of entrepreneurs' business plans (corporate social responsibility) or become the main driver for their activities, we see social entrepreneurs at play (Bailetti, 2012) (Fuller \& Tian, 2006) (Murphy \& Coombes, 2008). There are several arrangements that allow for pursuing both private and public goals. Particularly, academic entrepreneurship has more of an in-between status regarding private and public goals (Hillerbrand and Werker, in press): The university as such has public goals at heart, at the same time explicitly stimulating its staff members to make private and public entrepreneurship possible. The academic sector can stimulate private and public entrepreneurship in various forms including education, spin-off companies, consultancy reports, publications and patents (Perkmann, et al., 2013). Here, we use academic entrepreneurship in the broader sense by not only taking in spin-offs but also the aforementioned other academic engagement activities. Sometimes communities of consumers come together to jointly pursue their private and public goals, such as local neighbourhood initiatives of individually producing energy while at the same time reducing the negative effects of energy use on the local environment. Then we talk about civic communities or civic entrepreneurship (Fuller \& Tian, 2006).

\section{Entrepreneurs' relationships beyond their own sector}

Entrepreneurs build a network and collaborate with others in order to pursue their various goals as mentioned in the "Entrepreneurs in the private, public and academic sectors" section. They share knowledge about technologies and innovation, knowledge about markets and knowledge about formal and informal institutions. They collaborate to find new technological solutions, to change formal and informal institutions and to create new markets (Bailetti, 2012) (Landström, Harirchi, \& Åström, 2012).

In networks of various kinds of entrepreneurs, you potentially find all three sectors of the Triple Helix, i.e. the private, public and academic sectors (Etzkowitz \& Leydesdorff, 2000). Such networks of entrepreneurs can create opportunities and values as well as transfer of 
technological and social knowledge between collaborating partners (Gurrieri, 2013). The glue between various types of entrepreneurs pursuing different aims and using numerous strategies and tools, as well as their ability of taking changing roles in the course of time, depends a lot on the relationships between (potential) network partners (Gurrieri, 2013). Therefore, activities of entrepreneurs are embedded in complex technological systems and hinge on social processes supporting the "collective learning system[s] in which innovation and knowledge networks play a fundamental role" (Esparcia, 2014, p. 2). In the "Networks of entrepreneurs in the Dutch energy system: two cases" section, we analyse two collective learning systems emerging from the Dutch energy sector.

\section{Recent institutional and technological change of the Dutch energy system}

In the past two decades, the institutional set-up of the Dutch and Western-European energy systems has gone through large changes: from government-owned and controlled monopolies to privatized and liberalized markets in which households and businesses can choose their own electricity and gas provider. The Netherlands have taken a fairly progressive laissez-faire approach to energy and electricity production. They did so in unbundling production and distribution of energy and in leaving major investment decisions to energy companies more and more held by foreign owners (Verbong \& Geels, 2007).

The changes in the institutional set-up of the energy systems in Western Europe have led to a handful of producers providing electric production capacity. The concentration dynamic in the Netherlands has been similar to the UK, also a fossil-based energy system with a strong market focus and also dominated by a small set of large producers. Such an environment rather perpetuates vested interests and thus is not conducive to small-scale initiatives (Ligtvoet \& van Barneveld, 2016). Furthermore, according to advocates of stricter climate policies, the Dutch government has not sufficiently invested in sustainable energy solutions (Kern \& Smith, 2008). As a consequence, the Netherlands have lost their leading position in low-carbon technologies (e.g. wind) and have to look to Germany and Denmark for inspiration (Breukers \& Wolsink, 2007; Ligtvoet \& van Barneveld, 2016). Given this situation, Dutch entrepreneurs face even more challenges in taking entrepreneurial risk in a highly dynamic environment than entrepreneurs in surrounding countries.

Three trends have recently driven technological changes in Western-European countries, thereby affecting the Dutch energy system from three different directions:

1. Changes based on new sources of energy. While non-renewable energy sources have become increasingly scarce, demand for energy has been growing. To meet this growing demand, stakeholders have explored alternatives such as solar, wind, geothermal, biogas and biowaste energy. Particularly in recent years, developments in the costs of solar panels (Parida, Iniyan, \& Goic, 2011) have opened up new possibilities for individual consumers and small enterprises. While before small enterprises and individual consumers had individually little or no influence on the energy market, now their roles have changed substantially. In particular, the flow of energy is no longer unidirectional but has become bidirectional which leads to a change in roles (Chattoraj, 2014). As a consequence, energy providers have now also become clients of new entrants at the local level that produce renewable energy. At the same time, end users of electricity have become producers of energy themselves, selling on a local scale or supplying renewable energy through the grid operator. 
2. Changes in governance, i.e. from centralized control of the energy infrastructure to a more decentralized one. The liberalization in the energy markets together with technological changes in energy production and distribution has led to a situation of more decentralized but interconnected systems in which energy is not only produced by the traditional energy providers. These systems consist of the traditional energy suppliers and grid operators as well as of consumers, citizens and small energy companies that generate and sell electricity to the grid or to users in their neighbourhood.

3. Changes based on the use of smart information and communications technologies (ICT), such as the implementation of smart energy meters within a smart grid providing new services to end users in three ways. First of all, smart energy meters enable end users to match their energy consumption to the fluctuation in tariffs, once dynamic tariffs become available. This can contribute to balancing the energy supply to the energy consumption within certain time periods and lower costs for the consumer ( $\mathrm{Li}$, et al., 2010). Second, the smart energy grid leads to more transparent billing for the energy consumer. Third, the grid helps turning pure consumers into entrepreneurs not only consuming but also producing energy, the so-called prosumers.

These three main trends driving the energy system have emerged from collaborations of various kinds of entrepreneurs in electricity generation, transmission and distribution. The classic model of dominant large energy providers operating on a (inter)national level has gradually been replaced by a decentralized model of local initiatives at the edges of the national smart grid that generate electricity by a diversity of renewable sources to serve a community of users on a local level. In the "Networks of entrepreneurs in the Dutch energy system: two cases" section, we show two cases of these local initiatives. We focus on the kinds of entrepreneurs involved; on the evolution of their activities, roles and relationships; and on the resulting complexity on the infrastructural, technological and services level.

\section{Networks of entrepreneurs in the Dutch energy system: two cases Research approach and methods}

Our sample is based on theoretical considerations as suggested by Eisenhardt (1989). We picked the two cases Aardwarmte Den Haag (ADH) and LochemEnergie to replicate existing theory regarding entrepreneurship and to extend it towards the use of the Triple Helix. Particularly, we picked them as they are exemplary for sustainable energy solutions. At the same time, the cases differ considerably regarding their initiation, organization and technological approach, enabling us to detect diverging patterns of entrepreneurs and their networks in the Triple Helix. Aardwarmte Den Haag was initiated by the municipality of The Hague focusing on the realization of one specific technology. On the other hand, LochemEnergie is a bottom-up initiative with a projectbased approach. LochemEnergie gets its financial support from subsidies and therefore realizes sequential innovative applications of a diversity of green energy technologies.

To explore the dynamics and complexity of entrepreneurship in complex sociotechnical systems, we performed an in-depth analysis of these two local initiatives 
within the Dutch energy system. Based on the inventory of the main institutional and technological changes that influence the space for innovations in the energy sector (Recent Institutional and Technological Change of the Dutch Energy System), we analyse the cases over a period of time. The information provided on Aardwarmte Den Haag stems from a literature review and five interviews with the main stakeholders (municipality, energy companies, housing corporations and the project bureau) during the fall of 2012 (see Ligtvoet, 2012, 2013 for details). The information provided on LochemEnergie is based on an extensive literature review on academic literature as well as (local) government documents up until December 2016.

For the cases Aardwarmte Den Haag (see the "Aardwarmte Den Haag" section) and LochemEnergie (see the "LochemEnergie" section), we analyse the evolution of the local initiatives, their goals and incentives as well as the evolution of their knowledge network. By comparing the cases in the "The two cases compared" section, we are able to detect diverging patterns in the development of networks and in the changing roles of entrepreneurs.

\section{Aardwarmte Den Haag}

\section{The evolution of Aardwarmte Den Haag}

Aardwarmte Den Haag (ADH-Geothermal Heat The Hague) is aimed to use heat from geothermal layers for district heating in the city of The Hague. The Hague is situated in the west of the Netherlands and has approximately 400,000 inhabitants (see Ligtvoet, 2012, 2013 for details). Aardwarmte Den Haag started due to a coincidence: a civil servant of the municipality of The Hague department of Building Physics and Building Ecology inadvertently attended a congress organized by Stichting Platform Geothermie (Geothermal Foundation) in March 2004. Given the information on deep geothermal layers, the civil servant saw a window of opportunity for promoting sustainable heating in The Hague. This opportunity was strengthened when the private energy producer E.On Benelux, already providing district heating in the area, had to invest in new equipment and public and private interests started overlapping. The technical challenge was acknowledged but in its turn also created enthusiasm for the project, as illustrated by two quotes from the interviews we conducted:

The first project plans were superficial as only limited knowledge on such projects was available (interviewee)

The project was deemed technically complicated, but it created a lot of enthusiasm too. The return on investment was going to be relatively low, but this was accepted by the partners, partially to show their green image. (interviewee)

It turned out that the idea behind Aardwarmte Den Haag was able to combine the interests of public, semi-public and private partners: a consortium containing the municipality of The Hague, energy producer E.On Benelux and electricity and gas distributor Eneco. On the motivations and expectations in this phase, an interviewee mentions: "In the worst case you lose your investment, in the better cases you have initialised the first geothermal district/city heating project in the Netherlands."

Three locally operating housing corporations were asked to join the consortium as their planned restructuring and building activities in the southwest of The Hague 
provided the ideal market for heat. At the end of 2004, the consortium made its first preparations for technical feasibility studies. The required knowledge of geothermal and heat/cold storage, heat installations and underground heat layers also required a unique combination of expertise. No single organization had the knowledge of both surface and underground installations. So, this required the expertise of specialized technical consultants, as well as the involvement of the Netherlands Organisation for Applied Scientific Research TNO. Studies showed that the targeted geological layer did not contain sufficient water of $90{ }^{\circ} \mathrm{C}$, and the consortium chose an alternative approach: using the heat of a deeper layer (at approximately $60^{\circ} \mathrm{C}$ ) for heating newly built houses. This choice raised the estimated project costs from 6 to 10 million Euros to 45-50 million Euros, but the project still seemed promising. Therefore, the partners held several preparatory interviews and discussions.

In 2005, the consortium was ready to present their plans to a wider group of stakeholders. The municipality and the housing corporations provided additional funds for further investigations, and the consortium signed a declaration of intent in June 2006 to deliver geothermal energy to $4000-6000$ households. Notwithstanding the original enthusiasm, the project slowed down as participants pursued other goals. To avoid a standstill, the consortium appointed a former director of Siemens Netherlands as ambassador. Furthermore, the members agreed that they could only successfully cooperate if they could trust each other's financial motives and incentives. One of the interviewees mentions that: "The trust factor was important - also the fact that the partners could call each other at any time to check facts or ask additional questions." A subsidy from the national Unique Chances Agreement issued by the Dutch Ministry of Economic Affairs (UKR - for stimulating cooperation between market and non-market parties) gave the group the necessary support to draw up a business case, and several working groups were installed to work out details, under the leadership of an externally sourced project leader. Furthermore, one of the consulting companies benchmarked the geothermal project with other energy sources to show that it could achieve $\mathrm{CO}_{2}$ reductions at lower costs (Timár, 2010).

When the UKR subsidy was granted in April 2007, the consortium believed it had a feasible business case and Aardwarmte Den Haag was publicly announced. According to some interviewees in the studies by Ligtvoet $(2012,2013)$, this proved to be a point of no return: "Once we publicly announced our intentions, we had to see the project through" (interviewee).

The members of the consortium promoted the project within their own organizations. However, the financial crisis of 2008 turned out to be a major barrier: the building activities for the new dwellings slowed down; there would not be sufficient clients for the pumped-up heat. As the anticipated returns crumbled, the private consortium partners discussed culling the project. Moreover, the consortium had to obtain permits for drilling and building a heat station and a heat network from the Mining Authority. Again, the combination of activities required the expertise of different legal advisors: no single organization had all knowledge required. The local authorities granted the permits but concerned citizens living close to the planned well objected because of expected disturbances in the neighbourhood. The legal dispute was taken to the highest court in the Netherlands (the Raad van State), who dismissed the objections (Raad van State, 2010). 
By 2009, the consortium had to look for new technical solutions that would allow existing households, rather than newly purpose-built houses (which were behind schedule), to connect to the lower temperature heat source. From a commercial perspective, this made more sense as existing buildings have a higher heat requirement than new, low-energy houses (30-40 gigajoules (GJ) as opposed to $20 \mathrm{GJ}$ per household per year), meaning higher sales. The consortium partners again discussed the commercial feasibility of the project but decided that they would have to accept the project, even with a low return on investment. In an interview, this was illustrated as follows: "It is [...] needed that the partners accept that some activities are not performed at a commercial tariff, but at cost-price+. It should also be accepted that not all activities will be performed instantly: some flexibility in timing is required."

The drilling finally commenced in March 2010, and by November, it was clear that the wells would produce sufficient heat. The following setback was that the extracted water contained gas which had to be extracted at additional cost before the warm water could be distributed through the network.

At the end of 2011, Aardwarmte Den Haag was in operation, clients were receiving invoices and the heat station (for emergency generation capacity) was operational. Although the start had been slower than expected, the amount of connected households was increasing due to a growth in building activities. In June 2012, the Dutch Crown Prince officially opened the geothermal station. However, the project was still struggling: due to continued low revenues, Aardwarmte Den Haag had to file for bankruptcy in May 2013. Three years later, the infrastructure was still in place and the municipality, together with two new shareholders, reassessed the business case. Given increased national focus on sustainable energy, the project is restarted under the moniker Haagse Aardwarmte Leyweg (HAL). After cleaning the production wells, the project is planned to produce $7 \mathrm{MW}$ of heat by 2018 (HAL, 2017).

\section{Goals and incentives}

The consortium not only consisted of six main partners (municipality Den Haag-public; E.On Benelux, Eneco-private; and the housing corporations-semi-private), but a range of private, technical advisory organizations, as well as the Netherlands Organisation for Applied Scientific Research TNO. Furthermore, at least one self-employed individual was hired by the consortium as part-time project manager, and several individuals were involved as ambassadors and promoters of the project. In such a network, the range of goals is vast and includes those stated at the official organizational level and those that play a role at the individual/group level. For The Hague, the Aardwarmte Den Haag project was a means to reach its goals for sustainable development and sustainable housing. For the housing corporations, it contributed to goals of sustainability by providing residents with sustainable sources of heating. The technological partners, including TNO, were working at the cutting edge of knowledge on geothermal heat recovery. The energy companies initially treated the project as a normal profit-driven activity. However, as the project progressed, the return on investment requirements had to be revised downward. This initially did not lead to a termination of the project, as other motivations or incentives played a role: keeping in pace with technical and market development ("Keeping up with the Joneses") or active learning by doing and involving the organization-a practical, rather than a theoretical, exercise. One could argue that other involved parties were also 
in it for the profit, but an important driver that was mentioned in all interviews was the thrill of working at the technical edge of development as well as at a scale never seen before. Thus, the innovation itself became a driver. One of the main reasons for forming this consortium is that the required knowledge did not reside in one member. All members were already in their own knowledge networks, but by combining these, they were able to expand their reach.

\section{Knowledge network}

The project Aardwarmte Den Haag has gone through all stages of development, from ideation and initiation towards realization, actual use and eventually termination by bankruptcy but having a restart with a future growth scenario (see Fig. 1). Although profitability had been an issue in its early phases, the reduced amount of connections due to stagnating housing developments turned out to be the major issue in filing for bankruptcy.

The network of the project Aardwarmte Den Haag experienced faster and slower phases. The periods with increased interaction led to a tighter knitting of the network, while times of slack also led to loosening. The different project managers played an important role in maintaining the network and creating a shared level of commitment. The project itself was carried out at the municipal level. However, apart from the local level players The Hague and two housing corporations, the other parties involved were regional and national as well as international. The technical expertise required the involvement of national technical experts as well as the Dutch research institute TNO. Some of the legal issues regarding drilling permits had to be tackled at the national level. Also, the UKR subsidy was a national-level initiative (see Table 1 for the full actor network).

The project Aardwarmte Den Haag was started in a top-down fashion as the municipality of The Hague proactively initiated it. Yet, the municipality was supported by a foundation (Platform Geothermie) in the initial stages of the project and private partners joined early on too. The project took the legal shape of a partnership, in which the six original partners had an equal 1/6 share in capital and risk. Both in the initial

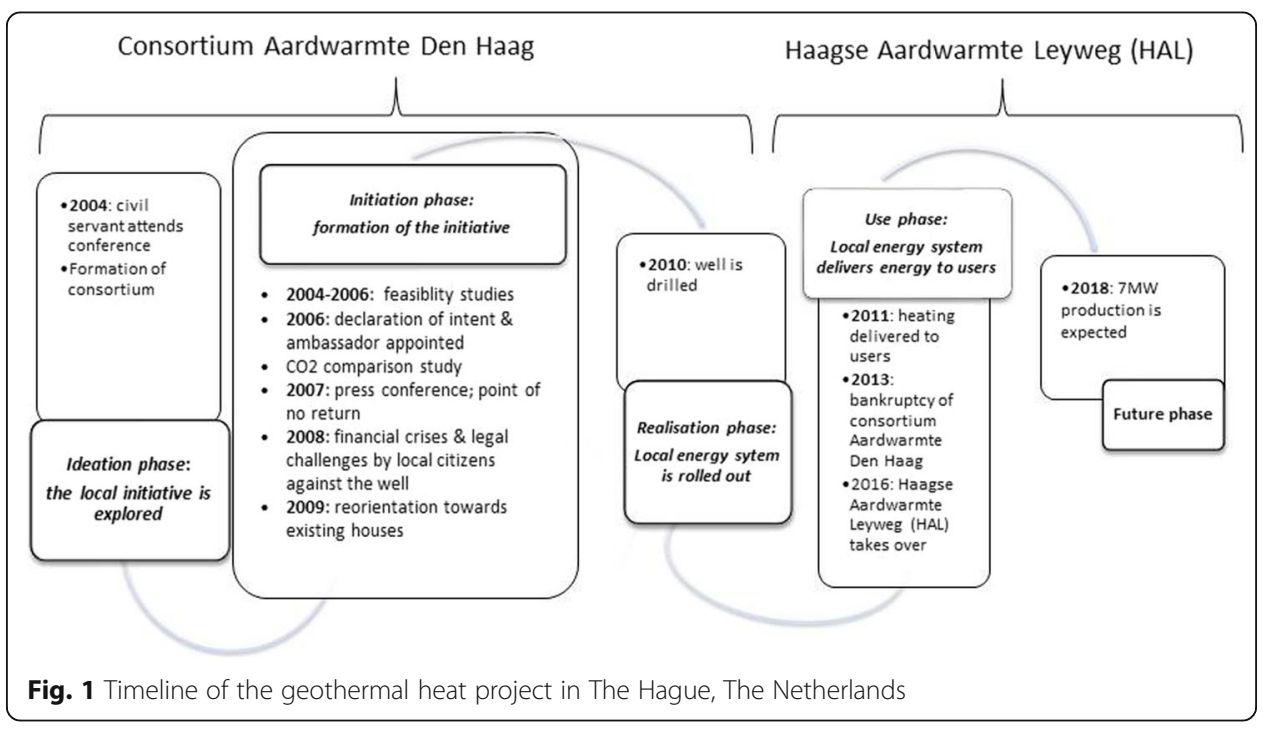


Table 1 The actor network of Aardwarmte Den Haag (2008-2013) and Haagse Aardwarmte Leyweg (2016-)

\begin{tabular}{llll}
\hline & Private entrepreneurs & Public entrepreneurs & $\begin{array}{c}\text { Academic } \\
\text { entrepreneurs }\end{array}$ \\
\hline Local & Local housing corporations & $\begin{array}{l}\text { Municipality of The Hague/ } \\
\text { The Hague Energy Fund }\end{array}$ & \\
Negional & $\begin{array}{l}\text { Distribution system operator: } \\
\text { Eneco, regional housing corporation }\end{array}$ & Mining Authority, Ministry & TNO \\
International & E.On Benelux & of Economic Affairs & \\
\hline
\end{tabular}

and in the final stages of the partnership, The Hague municipality played a role in shaping the partnership and in searching for other viable options for its continuation. Due to the size and the novelty of this project, the range of stakeholders was large-apart from the public/municipal and private partners, technical experts, lobby/interest groups, citizens (both for and against the development), local politicians and a local hospital (as a potential client) were involved. Thus, we find intertwined relationships between the public and private sectors.

\section{LochemEnergie}

The evolution of LochemEnergie

LochemEnergie is a local energy initiative in a rural area in the east of the Netherlands. It operates in the Lochem municipality consisting of approximately 33,000 inhabitants that are spread over 12 village centres in an area of approximately $215 \mathrm{~km}^{2}$ (CBS, 2015). The case is an example of Dutch local energy initiatives stimulating the use of alternative energy sources by means of local energy generation and/or services provision such as advice on energy conservation to citizens. One hundred ten of such local energy initiatives were erected by citizens in the Netherlands by early 2014 (Elzenga \& Schwenke, 2014, p. 14). The most common form of organization for these local initiatives is a cooperative: a non-profit institution of which energy consumers become members. The energy consumers thereby have a say in the appointment of the Board and in the general policy of the cooperative. Membership is required for those households, organizations and businesses that wish to receive the locally generated energy.

In 2011, the municipality of Lochem published a vision on its own role in the changes in society from an orientation on vertical governance towards a more horizontal style of governance (Gemeente Lochem, 2011). In this reorientation, the municipality positioned itself as a coordinating actor instead of a classical steering local government that favours a top-down governance approach. Part of this reorientation was the acknowledgement of the power of actor networks and the vision to give more room to grass-root initiatives (Gemeente Lochem, 2011). This policy context created a favourable environment for the emergence of bottom-up initiatives within the municipality (Egyedi et al., 2012). The driving force behind the cooperative of LochemEnergie was an alderman who acted as an advocate for the transition towards a sustainable future in his community (Hoppe et al., 2015).

The overall goal driving this local energy cooperative are lower energy costs for their members and independence from large energy companies (LochemEnergie, 2012). 
Particularly, the cooperative aims at keeping the expenditure on energy within its own vicinity, thereby creating local jobs. The long-term goal of the cooperative is to be a self-providing municipality in the domain of energy in 2030. Thus, the cooperative encompasses not solely the generation of local energy (by means of solar panels and possibly hydropower and wind mills) but more generally stimulates the use of renewable energy and the promotion of energy conservation. This has led to a proactive attitude towards energy conservation by means of a mix of activities. One example is the instalment of public charging stations for e-vehicles. Another one is the joint pool of seven e-vehicles that can be used by members of LochemEnergie (E\&E Advies en Drift, 2014). Additionally, LochemEnergie provides citizens with advice on energy savings via their website and by organizing information sessions for the inhabitants, e.g. on the use of LED bulbs, the instalment of sun power panels and housing isolation.

In the following, we take a look at the network of actors that are involved in the cooperative, the roles they play and the resources they provide to contribute to its development. In 2011, LochemEnergie was erected by six volunteers of the municipality that were looking for means to provide renewable energy to the local citizens (LochemEnergie, 2012). While these volunteers were private citizens, the ones who lead the board of the cooperative either run a private consultancy or work in the education system. Gradually, LochemEnergie has grown into a wider network of actors, including its citizen members ( 600 in 2016) and volunteering inhabitants. Eneco Green Energy services, part of the large Dutch energy provider Eneco Group ( 7000 employees, its shares are held by 53 Dutch municipalities (Eneco, 2014)) serves as a backup system to the local energy system for periods in which the local energy production does not suffice. In view of the long-term goal of being independent from large energy corporations, the role of Eneco as a backup provider is expected to diminish over time. In addition, the municipality of Lochem itself supported the cooperative by providing facilities such as allowing the cooperative to install collective sun collector parks on the roofs of the town hall. Also, the private press brake company WILA allowed the instalment of solar panels on the roofs of their construction hall for free (WILA, 2014). Other actors being part of the network are the local housing corporations. They team up with the cooperative to explore the options for energy savings in rental houses. Whereas the subscription to the local green energy is a task for the inhabitants themselves, the housing corporations look into ways to bring down the use of energy. They share knowledge and experiences with LochemEnergie to improve the sustainability of the rental houses.

Stepwise, LochemEnergie has pursued its goals (see Fig. 22). In November 2011, a classic windmill was transformed into the first Dutch mill to provide renewable wind energy for its own functioning. The expertise from the LochemEnergie cooperative was used to reach this goal (E\&E Advies \& Drift, 2014). Two pilot projects were particularly important to explore the opportunities of local energy generation. In January 2012, LochemEnergie participated in the pilot project called In4Energy. This project was part of a national innovation subsidy programme Intelligent Networks ("Intelligente Netten") of the Dutch Ministry of Economic Affairs. In this programme, 12 pilot projects were initiated to experiment with smart grid solutions. The programme was led by the Netherlands Enterprise Agency (RVO: Rijksdienst voor Ondernemend Nederland) (RVO.nl, 2015). Within the In4Energy project, LochemEnergie explored the 
implementation of a smart grid in a real-life context. Four main actors were involved in this pilot project, each contributing their own expertise and resources (RVO.nl, 2015). The first actor is the energy network operator Alliander with its knowledge in the domain of smart meters and the Intelligent Home System (HIS). Alliander also contributed to the development of a platform to service a virtual power plant (VPP). The second actor is the research group of Computer Architecture for Embedded Systems from the Technical University of Twente. The academic researchers focused on the control method to match energy supply and demand, the design of the ICT infrastructure and the interface design with the energy user. As a third actor, Eaton Industries was involved for their knowledge on the systems and components for electricity (software and hardware). The fourth actor was Locamation, a company that is specialized in smart grids and looked into the automation of the energy substations (RVO.nl, 2015). The pilot project showed the link between the local system level of LochemEnergie and the national level of knowledge exchange within a wider actor network. It also showed the complexity in developing a local energy initiative when the technology is not fully developed yet, which leads to uncertainties that need to be overcome by real-life testing.

The second pilot project that was important for the development of LochemEnergie aimed at the exploration of the possibilities to add energy from hydropower to their portfolio. Hydropower is considered a suitable source of energy to stabilize the fluctuations in the electricity generation from solar panel sources in times of insufficient sun power. Rijkswaterstaat (the Dutch public organization responsible for the maintenance of roads, waterways and water management) and the local water board Rijn and IJssel started to explore this option, which was still in its preparation phase in 2016 (see

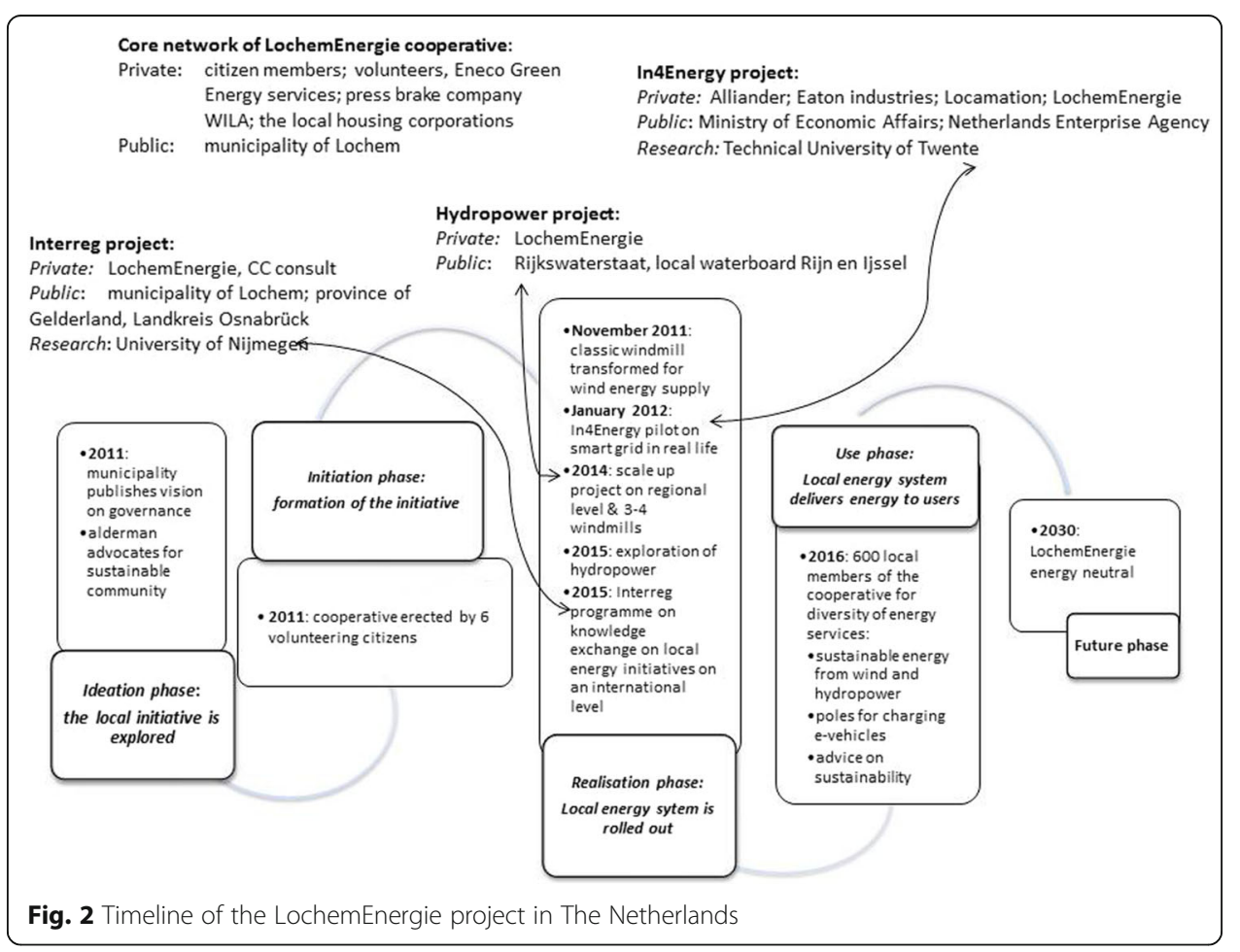


Fig. 2). The intention is to install a hydropower system in two local communities (LochemEnergie, 2012) (E\&E Advies and Drift, 2015).

In 2014, on the regional level, seven municipalities, including Lochem, explored options for regional sustainability with the vision to be an energy neutral region by 2030. In this regional plan, LochemEnergie is mentioned as an example to explore the feasibility of scaling up local projects into larger projects. The regional plan also mentions the option to install three to four modern windmills (E\&E Advies and Drift, 2015, p. 51 and 54).

On an international system level, knowledge exchange between German and Dutch local energy cooperatives have been explored within the Interreg programme Euregio (Interreg, 2015). In this project LochemEnergie, the municipality of Lochem, the province of Gelderland, the University of Nijmegen and Landkreis Osnabrück participate. Commissioned by LochemEnergie, the locally based consultancy firm CCI-project conducted an exploratory study to learn from each other's experiences and to explore options for specific communal real-life projects in the future.

The development of LochemEnergie as a bottom-up local energy cooperative led by volunteers is an example of an evolving civic community containing various kinds of entrepreneurs. The complexity of developing a local sustainable energy generation system requires the establishment of a knowledge network in which a diversity of actors are connected to explore new technological options. The complexity is high because of the use of new technological solutions that are not proven technology yet. The pilot projects show that, in addition to the core organization of LochemEnergie, new sets of actors collaborate to explore and create additional opportunities and support for local energy generation. These actors operate not only on the local system level, but also on the regional and even international system level (see Table 2 for the full actor network).

\section{Goals and incentives}

The main overall goal of LochemEnergie has been a local and regional energy system that will be neutral by 2030 (LochemEnergie, 2012). By becoming part of the circular economy, LochemEnergie wants to create local job opportunities and generate returns on investment beneficial for the municipality itself. In particular, it concentrates on the generation of local renewable energy, thus aiming at lower energy costs for the inhabitants. Thereby, LochemEnergie wants to become increasingly independent from large energy corporations and avoid (long distance) transport of energy that might lead to loss of energy.

Table 2 The actor network of LochemEnergie

\begin{tabular}{llll}
\hline & Private entrepreneurs & Public entrepreneurs & Academic entrepreneurs \\
\hline Local & $\begin{array}{l}\text { Citizens; volunteers; press } \\
\text { brake company WILA; local } \\
\text { housing corporations; CC } \\
\text { consult }\end{array}$ & Municipalities & \\
Regional & Alliander & & \\
& & Province of Gelderland; Local & \\
National & Eneco Green Energy Services; & Rijkswaterstaat; Dutch & Technical University of \\
& Eaton Industries B.V.; & Ministry of Economic Affairs; & Twente, the group of \\
& Locamation & Netherlands Enterprise & Computer Architecture for \\
& & Agency & Embedded Systems; \\
& & & University of Nijmegen \\
International & & Landkreis Osnabruck & \\
\hline
\end{tabular}




\section{Knowledge network}

The cooperative is rather young. After an invitation from an alderman of the municipality of Lochem, LochemEnergie was started by citizens in September 2010 and formally installed as a cooperative in August 2011 (RVO.nl, 2015). The cooperative shows an organic growth path that is taken by formulating projects in a diversity of forms to stimulate the generation and use of sustainable local energy. The cooperative started with sustainable energy generation by means of solar panels and moved onwards with the provision of poles for charging e-vehicles and the exploration of alternative forms of energy generation such as hydropower.

In the LochemEnergie case, a wide diversity of entrepreneurs from different sectors have collaborated to set up the initial organization as the core and to explore and test sustainable local energy sources in subsequent pilot projects. Implementing and testing innovative technical solutions under real-life conditions come with complex changes and inherent uncertainties. The projects of LochemEnergie have benefitted severely from the network, the knowledge and expertise of entrepreneurs from the Triple Helix.

\section{The two cases compared}

Both cases differ substantially in their organization. Whereas Aardwarmte Den Haag (ADH-Geothermal Heat The Hague) has emerged from the top-down organization of an energy community, LochemEnergie was initiated by six volunteers creating an energy community.

In the case of Aardwarmte Den Haag, it was the civil servant going to a workshop expecting a completely different kind of information and leaving with the idea for the project (Ligtvoet, 2012). In the case of LochemEnergie, it was the newly emerging governance vision of the municipality that trigged several projects on local sustainable energy solutions (Gemeente Lochem, 2011).

Both cases show how entrepreneurs from various sectors collaborate, thereby contributing to the dynamics of their part of the energy system. Although their starting point differs substantially, they share two features. First of all, the initiator of both was a public entrepreneur. Second, from the very start, the initiators heavily relied on an emerging network of entrepreneurs from the private, public and academic/research sectors. Various kinds of entrepreneurs have shared knowledge, designed plans, created organizational forms, innovated and collaborated to achieve sustainable energy solutions on the local level. Within the two networks, depending on their goals, incentives, knowledge, resources and policy levers, the organization and leadership have evolved and changed in the course of time. Particularly, various entrepreneurs have shared their perturbations and interacted with each other. Uncertainty and chance have been at the very heart of the evolution of both initiatives.

\section{Tentative framework of entrepreneurship in the Triple Helix}

\section{Characteristics of entrepreneurs and their relationships}

By investigating networks of different entrepreneurs in the Dutch energy system, we identified a number of characteristics for developing a tentative framework of entrepreneurship in the Triple Helix. In particular, it helps us to better understand the diversity and relationships of entrepreneurs in the energy system and beyond. 
Entrepreneurs stem from the private, public and academic sectors forming the Triple Helix. Their goals and incentives differ substantially governing their activities and roles throughout processes of finding sustainable energy solutions (see Table 3). Whereas private entrepreneurs, such as large energy companies or commercial start-up companies, have private goals of profit making and/or self-employment, public entrepreneurs, such as the municipalities, have public interests at heart, e.g. local sustainable energy solutions at a reasonable price. In the two local energy initiatives depicted in the "Networks of entrepreneurs in the Dutch energy system: two cases" section, we detect a lot of organizations combining private and public goals, such as LochemEnergie going for the sustainable energy solutions but also for local job opportunities and attaining returns on investment that are beneficial for the local community. As entrepreneurs do not have all relevant knowledge in-house, they look for partners that can complement their knowledge, often from other sectors. The organizational forms chosen depend on the goals, incentives, knowledge resources and policy levers. Depending on the situation, leadership within the chosen organization still might change over time.

\section{Entrepreneurs networking in the Triple Helix}

The results of our analysis in the "Networks of entrepreneurs in the Dutch energy system: two cases" and "Characteristics of entrepreneurs and their relationships" sections show that entrepreneurs rely on network partners to create and implement innovative technological solutions in the Dutch energy sector. Systems driven by the Triple Helix, i.e. the interaction between the private, public and academic sectors, are, in contrast to the Double Helix, not necessarily stable (Etzkowitz \& Leydesdorff, 2000). In a Triple Helix, the sources of innovation are not necessarily synchronized and might generate puzzles for entrepreneurs from the private, public and academic sectors to solve. The crucial question is how much a network of entrepreneurs can deal with to control the dynamics emerging from innovations substantially changing the energy system. The uncertainty and chance processes underlying the perturbations and interactions among the subsystems lead to situations in which networks can change substantially, so they dissolve and re-emerge, e.g. the consortium of Aardwarmte Den Haag had to file for bankruptcy but new shareholders saw the opportunities of the infrastructure investments (see the "Aardwarmte Den Haag" section).

Table 3 Characteristics of entrepreneurs and their relationships

\begin{tabular}{|c|c|c|c|c|}
\hline & \multicolumn{2}{|l|}{ Private entrepreneurs } & \multirow{2}{*}{$\begin{array}{l}\text { Public } \\
\text { entrepreneurs }\end{array}$} & \multirow[t]{2}{*}{ Academic entrepreneurs } \\
\hline & Profit-oriented firms & Civic entrepreneurs & & \\
\hline Goals & Private goals & $\begin{array}{l}\text { Private and public } \\
\text { goals }\end{array}$ & Public goals & Public goals \\
\hline $\begin{array}{l}\text { Incentives } \\
\text { (examples) }\end{array}$ & $\begin{array}{l}\text { - Profit or self- } \\
\text { employment } \\
\text { - Using engineering in } \\
\text { creative ways } \\
\text { - Being the most } \\
\text { important player in } \\
\text { the industry }\end{array}$ & $\begin{array}{l}\text { - Profit and energy } \\
\text { sustainability in local } \\
\text { communities } \\
\text { - Local job creation }\end{array}$ & $\begin{array}{l}\text { - Energy } \\
\text { sustainability in } \\
\text { local communities }\end{array}$ & $\begin{array}{l}\text { - Societally and } \\
\text { economically applicable } \\
\text { research solutions }\end{array}$ \\
\hline $\begin{array}{l}\text { Examples of } \\
\text { entrepreneurs }\end{array}$ & $\begin{array}{l}\text { Eneco; Alliander; } \\
\text { E.On Benelux }\end{array}$ & LochemEnergie & $\begin{array}{l}\text { Municipality of The } \\
\text { Hague }\end{array}$ & $\begin{array}{l}\text { Research institute TNO; } \\
\text { Universities: Technical } \\
\text { University of Twente; } \\
\text { University of Nijmegen }\end{array}$ \\
\hline
\end{tabular}


To some extent, entrepreneurs can deal with inherent uncertainty by negotiation, particularly by shaping their environment (partially) to their own image (Sarasvathy, 2003). In both cases we investigated, entrepreneurs have taken on different roles and negotiated solutions in the light of their own and their partners' goals and incentives, using their resources and policy levers. They have explored new scientific, economic and political possibilities in the context of flux and reorganization (Leydesdorff, 2012) (Etzkowitz \& Leydesdorff, 2000). In advanced societies, such as the Netherlands, institutional control is divided into the public and private domains (Etzkowitz \& Leydesdorff, 2000). Accordingly, in both cases, complex subsystems emerge by integrating and differentiating. While the original initiative has been local, actors from the regional, national and global levels have been included whenever necessary or useful.

The results of our analysis point to initiatives that potentially changed the established energy system. In the case of Aardwarmte Den Haag, with hot underground water, a sustainable energy source was found. To provide energy for households with this water, the network of entrepreneurs had to overcome numerous technological obstacles and find ways to deliver the energy to the households by changing their part of the energy system. In the case of LochemEnergie, entrepreneurs have been looking for various solutions to provide the region with local and sustainable energy. They came with various innovations, changing the way the energy infrastructure is set up and used. In both cases, entrepreneurs have been units of economic coordination and control including administrative structures that add value to human and material resources through collective work organization and entrepreneurial decision-making (Brookes, Brewster, \& Wood, 2005).

Our results point to the different roles that entrepreneurs from the private, public and academic sectors have adopted. "The Triple Helix denotes not only the relationship of university, industry and government, but also internal transformation within each of these spheres" (Etzkowitz \& Leydesdorff, 2000, p. 118). Private entrepreneurs can rely neither on clearly defined boundaries nor well-established rules of engagement because there are no established practices and no taken-as-given environment (Dew, Read, Sarasvathy, \& Wiltbank, 2008). Here, private entrepreneurs face a design problem rather than an adaptation problem, i.e. they do not need to adapt to a slowly changing environment but need to find their way in a substantially changing one (Dew, Read, Sarasvathy, \& Wiltbank, 2008), i.e. a change that considerably affects the network (Werker, 2001). In the two cases depicted in the "Networks of entrepreneurs in the Dutch energy system: two cases" section, it becomes clear that private entrepreneurs create variation by technological innovation and face selection mechanisms provided by the regulated markets within the institutional set-up of the energy system. In addition, public entrepreneurs were crucial to start the initiatives. However, although one initiative was started in a more top-down fashion and the other one in a bottom-up fashion, in both cases, we see them acting in an enabling instead of controlling way. In this sense, they are very much in line with public policies in a Triple Helix context as they provide reflexive feedbacks in evolving systems (Etzkowitz \& Leydesdorff, 2000). Academic entrepreneurs provide the so-called third mission activities, i.e. translating academic insights into societally and economically relevant solutions.

\section{Conclusions}

In this paper, we show (1) that indeed entrepreneurship goes beyond the private standalone enterprises and (2) that networks of entrepreneurs stemming from the academic, 
industrial and governmental sectors are necessary to realize technological innovations potentially changing a whole system. These networks of entrepreneurs can be usefully captured by the Triple Helix concept, because this concept gives justice to the different roles, goals, incentives, resources, knowledge and policy levers of entrepreneurs from the private, public and academic sectors (see the "Tentative framework of entrepreneurship in the Triple Helix" section). Particularly, it depends on the actual situation on who has the incentives and resources to be in charge and act and to include others when it seems necessary. In both cases analysed here, public entrepreneurs took the initiative. While in the case of Aardwarmte Den Haag, a number of key players collaborated in order to realize one technology, in the LochemEnergie case, we see a projectto-project approach driven by subsidies.

Regarding management and policy recommendations, entrepreneurs from the private, public and academic sectors all require particular skills including the ability to engage with their (knowledge) network, identify gaps, attract new participants and motivate the new and existing participants. As entrepreneurs managing these networks handle a whole range of semi-unpredictable actors and environmental factors that also influence each other, we look at truly complex socio-technological systems. Entrepreneurs from all sectors have a modest role in steering participations in networks. They have to monitor the status of the network and identify needs and gaps as the developments do not necessarily follow a fixed scheme. Rather, developments of local energy initiatives unfold along the way. This requires entrepreneurs to be flexible (Mintzberg \& Waters, 1985) and open to organizational change (Sarasvathy, 2003). While large organizations such as municipalities or large multinational companies are less flexible, they might create space for smaller entrepreneurial activities by supporting individuals, start-ups or academics in finding novel solutions. A major role for public entrepreneurs lies in stimulating and subsidizing entrepreneurs and their networks (Elzenga \& Schwenke, 2014).

Our results rely on two cases of the Dutch energy system. Both initiatives have been driven by the goal of finding sustainable energy solutions and including them into a local system. Therefore, we need to critically examine the applicability of the tentative framework provided in the "Entrepreneurs networking in the triple helix" section. We suggest that in principle, the high-level actors and incentives as depicted in Table 3 hold for all systems where networks of entrepreneurs play a role. Entrepreneurs from private, public and academic sectors would be involved; sometimes civic entrepreneurs take a prominent role such as in the LochemEnergie case; in other situations, academia takes an advisory instead of engineering role, such as in the Aardwarmte Den Haag case. At the same time, we question whether initiatives outside energy systems or other still rather heavily regulated systems would be started by a public entrepreneur as has been the case in the two initiatives presented here. Less regulated systems are more governed by market selection mechanisms, e.g. the market for Big Data applications, and might show substantially different evolutions being started by private or academic entrepreneurs. Moreover, we suggest that our results hold mainly for advanced economies with strong private, public and academic sectors being able to change roles depending on the necessities of technological requirements as well as economic and societal needs. Governments in such countries might wish to consider two aspects of our results: First, in the light of little top-down traction for energy transformation towards renewables in the Dutch energy system, bottom-up initiatives of networks of 
entrepreneurs drive the transformation. Second, the bottom-up initiatives driving the transformation of the Dutch energy system depend heavily on public funding. In this context, governments need to consider if and for how long they want to subsidize these kinds of initiatives or employ other instruments to allow room for innovation on a local level, at the edge of the national grid.

In line with the limitations of our results, we suggest that promising roads of further research are at least twofold. First of all, it would be fruitful to carry out more detailed research into different development stages and the required entrepreneurial skills as well as network set-up and resources in different stages. Second, to get a fuller picture we need to investigate other kinds of systems than the still rather heavily regulated energy system and other countries than the advanced society of the Netherlands.

\title{
Additional file
}

Additional file 1: Translation of the abstract into Arabic. (PDF 244 kb)

\begin{abstract}
Abbreviations
ADH: Aardwarmte Den Haag (Geothermal Heat The Hague); $\mathrm{CO}_{2}$ : Carbon dioxide; GJ: Gigajoule; NGO: Non-governmental
\end{abstract} organization; SME: Small and medium enterprise; UKR: Unique Chances Agreement

Funding

The research reported in this article has not been funded by external parties.

\section{Authors' contributions}

CW provided the theoretical positioning of the case studies and developed the research framework. AL provided the case study on Aardwarmte Den Haag/Geothermal The Hague. JU provided the case study on LochemEnergie. All authors wrote parts of the initial manuscript, read and approved the final manuscript.

Competing interests

The authors declare that they have no competing interests.

\section{Publisher's Note}

Springer Nature remains neutral with regard to jurisdictional claims in published maps and institutional affiliations.

\section{Author details}

${ }^{1}$ Faculty of Technology, Policy \& Management, Delft University of Technology, Delft, The Netherlands. ${ }^{2}$ Technopolis Group, Amsterdam, The Netherlands.

Received: 3 November 2016 Accepted: 20 November 2017

Published online: 04 December 2017

\section{References}

Audia PG, Rider Cl (2005) A garage and an idea: what more does an entrepreneur need? Calif Manag Rev 48(1):6-28

Bailetti T (2012) Technology entrepreneurship: overview, definition, and distinctive aspects. Technology Innovation Management Review 5-12. http://timreview.ca/sites/default/files/article_PDF/Bailetti_TIMReview_February2012.pdf

Breukers S, Wolsink M (2007) Wind power implementation in changing institutional landscapes: an international comparison. Energy policy 35(5):2737-2750

Brookes M, Brewster C, Wood G (2005) Social relations, firms and societies: a study of institutional embeddedness. Int Sociol 20(4):403-426

CBS (2015) Gemeente Lochem: bevolking; geslacht, leeftijd, burgerlijke staat en regio, January 1 st 2015 and: Bodemgebruik; uitgebreide gebruiksvorm, per gemeente, 11 Aug 2015

Chattoraj B (2014) From greening of ICT to greening by ICT. Exploration of an open ICT platform for energy monitoring towards a sustainable economy. Master thesis, Delft: Delft University of Technology. https://repository.tudelft.nl/ islandora/object/uuid\%3Ad53e9329-5ea2-40a8-85e5-5fb64c7297e3?collection=education.

Dew N, Read S, Sarasvathy S, Wiltbank R (2008) Outlines of a behavioral theory of the entrepreneurial firm. J Economic Behavior and Organization 66:37-59

E\&E Advies \& Drift (2014) Nieuwe energie voor de Stedendriehoek. Routekaart naar een energieneutrale regio Stedendriehoek in 2030. (New Energy for the Stedendriehoek. Roadmap towards an energy neutral region Stedendriehoek in 2030) Groningen/Rotterdam: E\& E Advies \& Drift, March 2014

Edquist C (2011) Design of innovation policy through diagnostic analysis: identification of systemic problems (or failures). Ind Corp Chang 20(6):1725-1753

Egyedi T, Vrancken J, Ubacht J (2012) Inverse infrastructures: coordination in self-organizing systems In: Egyedi TM, Mehos DC (eds.) Inverse infrastructures: disrupting networks from below. Edward Elgar, Cheltenham, pp 291-311 
Eisenhardt KM (1989) Building theories from case study research. Acad Manag Rev 14(4):532-550

Elzenga H, Schwenke AM (2014) Energiecoöperaties: ambities, handelingsperspectief en interactie met gemeenten. (Energy cooperatives: ambition, acting perspective and interaction with municipalities). The Hague: Planbureau voor de Leefomgeving, report no. 1371, ISBN 978-94-91506-56-9 Planbureau voor de Leefomgeving

Eneco (2014) Yearly report 2014

Esparcia J (2014) Innovation and networks in rural areas. An analysis from European innovative projects. J Rural Studies 34:1-14

Etzkowitz H, Leydesdorff L (2000) The dynamics of innovation: from National Systems and "mode 2" to a triple helix of university-industry-government relations. Res Policy 29:109-123

European Commission (2013) Options for strengthening responsible research and innovation. Directorate-General for Research and Innovation, Luxembourg

European Commission (2017) Renewable energy progress report. COM(2017) 57, Brussels 1.2.2017

Fuller T, Tian Y (2006) Social and symbolic capital and responsible entrepreneurship: an empirical investigation of SME narratives. J Business Ethics 67(3):287-304

Gemeente Lochem (2011) Toekomstvisie 2030. Lochem verbindt prachtig (Lochem Vision on the Future 2030. Lochem connects beautifully). Lochem: Lochem Municipality, April 4th 2011.

Gibson DV, Stiles CE (2000). Technopoles, technology transfer and globally networked entrepreneurship. In: Conceição DV, Gibson M, Heitor, Shariq S. Science, technology, and innovation policy: opportunities and challenges for the knowledge economy. The Icp2s Management and Management Science Serie, No. 8. Westport: Praeger, U.S. pp. $195-207$

Godin B (2006) The linear model of innovation. The historical construction of an analytical framework. Science, Technology and Human Values 31(6):639-667

Gurrieri AR (2013) Networking entrepreneurs. J Socio-Economics 47:193-204. doi:10.1016/.jocec.2013.09.007

HAL: Website Haagse Aardwarmte Leyweg, http://haagseaardwarmte.nl, last consulted on March 17th, 2017

Henton D, Melville J, Walesh K (1997) The age of the civic entrepreneur: restoring civil society and building economic community. Natl Civ Rev 86(2):149-156

Hillerbrand R, Werker C (in press) Values in university-industry collaborations: the case of academics working at universities of technology. Sci Eng Ethics

Hoppe T, Graf A, Warbroek B, Lammers I, Lepping I (2015) Local governments supporting local energy initiatives: lessons from the best practices of Saerbeck (Germany) and Lochem (the Netherlands) sustainability 7, pp 1900-1931. doi:10.3390/su/7021900

Interreg Deutschland-Nederland (2015) Kooperationsprogramm 2014-2020. Version 2.1, 30.11.2015.https://www. deutschland-nederland.eu/wp-content/uploads/2015/12/151130_Kooperationsprogramm_INTERREG_DeutschlandNederland de.pdf Accessed 23 Dec 2015

Kern F, Smith A (2008) Restructuring energy systems for sustainability? Energy transition policy in the Netherlands. Energy policy 36(11):4093-4103

Klein PG, Mahoney JT, McGahan AM, Pitelis CN (2010) Toward a theory of public entrepreneurship. Eur Manag Rev 7(1):1-15

Landström H, Harirchi G, Åström F (2012) Entrepreneurship: exploring the knowledge base. Res Policy 41(7):1154-1181

Leydesdorff $\mathrm{L}$ (2012) The triple helix, quadruple helix, ..., and an N-tuple of helices: explanatory models for analyzing the knowledge-based economy? J Knowledge Economy 3(1):25-35

Li F, Qiao W, Sun H, Wan H, Wang J, Xia Y, Zhang P (2010) Smart transmission grid: vision and framework. IEEE Transactions on Smart Grid 1(2):168-177

Ligtvoet A (2012) Factors supporting cooperation in district heat networks in the Netherlands. Design and governance in engineering systems. Paper presented at the Cesun third international engineering systems symposium, Delft University of Technology, 18-20 June 2012

Ligtvoet A (2013) Images of cooperation-a methodological exploration in energy networks, Dissertation, Delft University of Technology. doi:10.4233/uuid:8f285238-4e87-4517-83a9-5167efb52eb1

Ligtvoet, A, J van Barneveld (2016) Internationaal Vergelijk van Energietransities [international comparison of energy transitions] + country studies Belgium, Denmark, Germany, France, UK, Technopolis group, Amsterdam, December 2016

LochemEnergie (2012) LochemEnergie wil eigen Lochemse energie! https:/www.lochemenergie.net/ Accessed 3 Feb 2017

Ministry of Economic Affairs (2016) Energieagenda - naar een CO2-arme energievoorziening (energy agenda - towards a CO2 reduced energy supply system) The Hague: Ministry of Economic Affairs, December 2016

Mintzberg H, Waters J (1985) Of strategies, deliberate and emergent. Strat Mgt J 6(3):257-272

Murphy PJ, Coombes SM (2008) A model of social entrepreneurial discovery. J Business Ethics 87(3):325-336

Parida B, Iniyan S, Goic R (2011) A review of solar photovoltaic technologies. Renew Sust Energ Rev 15(3):1625-1636

Perkmann M, Tartari V, McKelvey M, Autio E, Broström A, D'Este P et al (2013) Academic engagement and commercialisation: a review of the literature on university-industry relations. Res Policy 2(2):423-442. doi:10.1016/j.respol.2012.09.007

Raad van State (2010) Uitspraak 200907558/1/M1. The Haque: Raad van State, April 14th 2010

RVO.nl (2015) Lokale Duurzame Energie Bedrijven. http://www.hieropgewekt.nl/initiatieven. Accessed 3 June 2016

Sarasvathy S (2003) Entrepreneurship as a science of the artificial. J Economic Psychology 24:203-220

Sociaal Economische Raad (2013) Energieakkoord voor Duurzame Groei (energy agreement for sustainable growth) The Hague: Sociaal Economische Raad. September 2013

Timár E (2010) Den Haag primeur met aardwarmtewoning. Agentschap NL, Utrecht

Verbong G, Geels F (2007) The ongoing energy transition: lessons from a socio-technical, multi-level analysis of the Dutch electricity system (1960-2004). Energy policy 35(2):1025-1037

Werker C (2001) Knowledge and organization strategies in innovation systems. Intl J of Innovation Mgt 5(1):105-127

WILA (2014) Zonnepark op dak WILA (Solar park on roof WILA). Press release, 26 Sept 2014, http://www.wila.nl/ Zonnepark-op-dak-WILA.aspx?NL-5-294-0, Accessed 3 Sept 2016

Woodward D, Figueiredo O, Guimarães P (2006) Beyond the Silicon Valley: university R\&D and high-technology location. J Urban Economics 60(1):15-32 